\title{
Extreme Necrosis in an Italian Wall Lizard (Podarcis sicula)
}

\author{
Steven J.R. Allain ${ }^{1}$ and Riccardo Giulio Mattea ${ }^{2}$ \\ ${ }^{1} 11$ Trafalgar Way, Braintree, Essex, CM7 9UX, United Kingdom (steveallain@live.co.uk) \\ ${ }^{2}$ Via Oberdan 21, Terni (TR), 05100, Italy (riccardo.mattea@hotmail.it)
}

A $\mathrm{t}$ approximately $1200 \mathrm{~h}$ on 3 January 2017, RM discovered a female Italian Wall Lizard (Podarcis sicula) with a severely necrotized right hind leg (Fig. 1) in a residential backyard in the city of Terni in the Umbria region of Italy at an elevation of $150 \mathrm{~m}$ asl. The lizard was first observed when a plant pot, beneath which it had sought shelter, was moved. It was obviously not moving in the usual fashion when initially startled. A closer inspection revealed substantial damage to the right rear limb.

The female, with SVL of $9.0 \mathrm{~cm}$ and total length of ca. 18-19 cm, was of adult size (Arnold and Ovenden 2002). This injury might have been the result of a failed predation attempt by one of the numerous cats in the area where the observation took place. Unfortunately, the individual had no ability to move any part of the limb from the hip, due to the extreme levels of damage caused by necrosis. Nevertheless, the lizard did not seem to be seriously impaired by the loss of movement of the leg and was able to find a sheltered location to bask in the sun after being disturbed. It subsequently disappeared into the undergrowth.

Terni is located in a fertile valley that, despite the presence of a large city, provides suitable habitat for several taxa. Habitats range from cultivated countryside to deciduous mixed woodland. The climate is temperate. Summer months are generally humid and warm with low winds; winters are cold, with considerable precipitation and the possibility of snow. According to Capula and Ceccarelli (2003), popula-

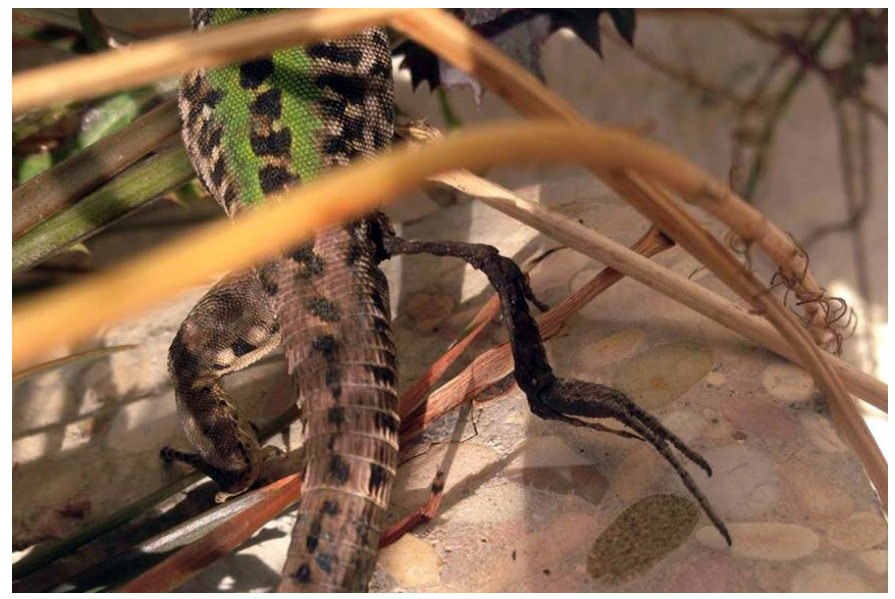

Fig. 1. An adult female Italian Wall Lizard (Podarcis sicula) with extreme necrosis of the rear right limb. Photograph by Riccardo Giulio Mattea.

tions of both $P$. sicula and P. muralis occur in much of Italy, including Umbria, where both species seem to sustain viable populations despite sometimes intense predation from domestic and feral animals.

\section{Literature Cited}

Arnold, E.N. and D. Ovenden. 2002. Collins Field Guide to the Reptiles and Amphibians of Britain and Europe. HarperCollins Publishers, New York, New York.

Capula, M. and A. Ceccarelli. 2003. Distribution of genetic variation and taxonomy of insular and mainland populations of the Italian Wall Lizard, Podarcis sicula. Amphibia-Reptilia 24: 483-495. 